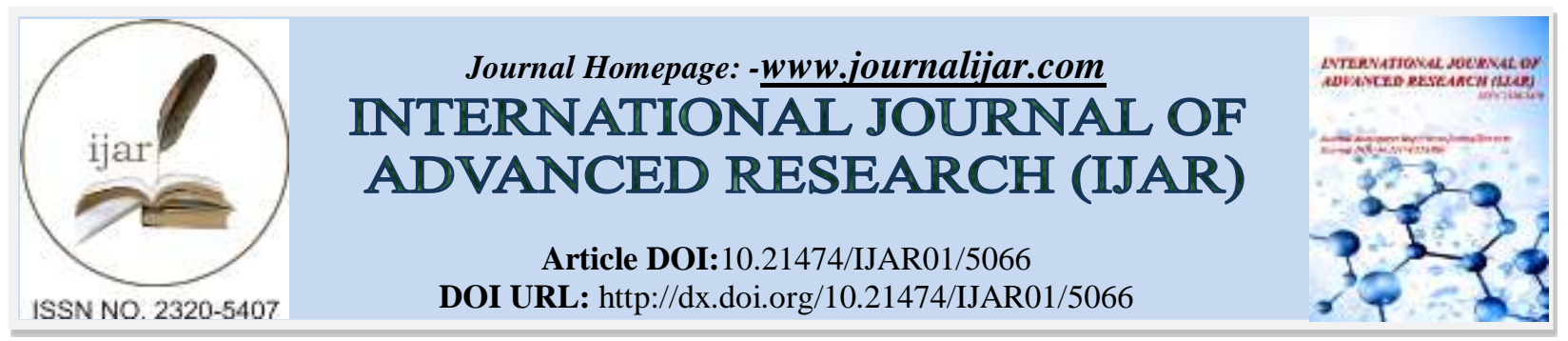

RESEARCH ARTICLE

\title{
Fe CONTENT AND ANTIOXIDANT ACTIVITY OF COOKIES WITH ADDITION OF BANANA (MUSA PARADISIACA) FLOUR AND KATUK (SAUROPUS ANDROGYNOUS) LEAVES FLOUR.
}

\author{
Rina Yenrina, Kesuma Sayuti and Widya Ningsih. \\ Faculty of Agricultural Technology, Andalas University. Kampus Limau Manis - Padang. West Sumatera,Indonesia \\ 25163.
}

\section{Manuscript Info}

Manuscript History

Received: 04 June 2017

Final Accepted: 06 July 2017

Published: August 2017

Key words:-

Antioxidant activity, banana flour, cookies, Fe, katuk leaves flour.

\begin{abstract}
This research was aimed to determine the influence of addition banana flour and katuk leaves flour on cookies characteristic especially $\mathrm{Fe}$ content and antioxidant activity. This research used a Completely Randomized Design (CDR) consists of 3 treatments and 3 replications, The treatment was mixing wheat flour,banana flour and katuk leaves flour: A (55\% : 40\%: 5\%), B (55\%: 35\%: 10\%), C (55\%: 30\%: 15\%). The observation of raw materials were water content, crude fiber content and $\mathrm{Fe}$ content. The observations of cookies were water content, ash content, protein content, fat content, carbohydrate content, Fe content, crude fiber content, antioxidant activity, free fatty acids content and hardness. The results of research showed that the addition of banana flour and katuk leaves flour had significant effect on water content, ash content, fat content, protein content, antioxidant activity, Fe content, and hardness but no significant effect on carbohydrates content, free fatty acids content and crude fiber content.
\end{abstract}

Copy Right, IJAR, 2017,. All rights reserved.

\section{Introduction:-}

Banana flour is rich in carbohydrates as well as various other minerals. Banana flour can be used as a mixture of ingredients found in all flour-based foods such as bread, cakes, biscuits, cookies and so on. Banana flour has a high carbohydrate that is about $88.6 \%$ (Mulyati, 2005).

Katuk has a functional role in health. People believe that by consuming katuk leaves can boosts the production of breast milk and various diseases such as lowering fever and treating yaws. Katuk leaves contains a quite high of fiber and Fe (Lingga, 1998). According to Limantara (2004), katuk rich of component has an antioxidant activity.

These days katuk much consumed by way of cooked as vegetable. To increase public consumption of katuk, it is needs a proper processing technology. One of them is by processing katuk leaves into flour so it can be used as a raw material for making food products, such as for making cookies.

Cookies are types of biscuits made from soft dough, high-fat, crunchy and when broken with cross section the texture is solid or porous. Cookies are a popular food product for people of all ages. Making cookies usually use wheat flour. The ingredients of cookies include flour, fat, sugar, milk, eggs and developer agent. Cookies also has a high calories because they contain high fat and sugar (Matz, 1978).

Corresponding Author:-Rina Yenrina.

Address:-Faculty of Agricultural Technology, Andalas University. Kampus Limau Manis - Padang.

West Sumatera,Indonesia 25163. 
Based on the above background, the author intended to conduct a study entitled "Fe Content and Antioxidant Activity of Cookies with Addition of Banana (Musa paradisiaca) Flour and Katuk Leaves (Sauropus androgynous) Flour".

\section{Methodology:-}

This research had been conducted at Laboratory of Chemistry, Biochemistry of Agricultural Product and Food Nutrition, Technology and Engineering Process of Agricultural Product Technology. Faculty of Agricultural Technology. Andalas University. Padang.

\section{Materials and Tools:-}

The materials needed in this research were wheat flour, banana and katuk leaves obtained from Bandar Buat Market, Padang City. Other ingredients used in cookies formulations include egg yolk, margarine, vanilla, butter, skim milk, refined sugar, salt and baking powder. The materials used for chemical analysis were sulfuric acid, aquades, boric acid, $\mathrm{HNO}_{3}, \mathrm{NaOH}$, calcium sulphate, $\mathrm{HCl}$, hexane, $\mathrm{KMnO}_{4}$, phenolphthalein indicator, acetic acid, sulfuric acid, methanol solution, alcohol, filter paper and other materials.

The tools used in this research were analytical scale, mixer, spoon, pans, oven, cabinet dryer, spectrophotometer, baking sheet, sieve, blender and plastic containers. The tools used for analysis are analytical scales, porcelain cups, furnace, Kjeldahl flasks, pipettes, soxhlet tools and other glassware needed.

\section{Research Design:-}

The design used in this study was Completely Randomized Design (CRD) with 3 treatments and 3 replications. If the results shows the difference due to the treatment given then it is followed by Duncan's New Multiple Range Test (DNMRT) test at 5\% level. Based on pre-research that has been done so that there is a basis in determining this treatment. The treatment used in this study were:

Treatment $\mathrm{A}=\mathrm{WF} 55 \%: \mathrm{BF} 40 \%: \mathrm{KF} 5 \%$

Treatment B = WF $55 \%:$ BF $35 \%:$ KF $10 \%$

Treatment C = WF $55 \%:$ BF $30 \%:$ KF $15 \%$

$\mathrm{WF}=$ Wheat Flour $\mathrm{BF}=\mathrm{Banana}$ Flour, $\mathrm{KF}=$ Katuk Leaves Flour

\section{Implementation:-}

Making Banana Flour:-

1. Preferred bananas that are ripe but not mature enough then removed from the set then washed and cleaned from dirt.

2. Then banana steamed for 10 minutes to easier the peeling and remove the sap.

3. Bananas drained and peeled, then sliced transversely and soaked in $2.000 \mathrm{ppm}$ sodium bisulfite for 5 minutes to prevent browning process.

4. Dried with oven with temperature $60^{\circ} \mathrm{C}$ for 10 hours.

5. After the banana dried, crushed with a blender, then dried bananas sieved through 60 mesh, then got banana flour. Packed with plastic clips and stored in food container.

\section{Making Katuk Leaves Flour:-}

1. Fresh green katuk leaves cleaned, sorted and taken leaves only.

2. Blanchingkatuk leaves first for 1 minute at a temperature of about $80^{\circ} \mathrm{C}$.

3. Then dried using Cabinet Dryer for 5 hours or until katuk leaves dry and can be broken.

4. The obtained dried katuk leaves are blended and sieved with a 60 mesh sieve.

5. The flour that passed the sieve packed with plastic clip and stored in food container.

\section{Making Cookies:-}

1. Margarine, egg yolk and refined sugar mixed with medium speed mixer for 5 minutes.

2. Add wheat flour, banana flour, katuk leaves flour, skim milk, vanilla, salt and baking powder and stirred again for 2 minutes with the mixer.

3. After the dough formed, let it for 5 minutes to relax the dough.

4. The dough flattened with a thickness of $0.5 \mathrm{~cm}$.

5. Then do the molding process with mold and placed on the baking sheet. 
6. The result of mold is baked 15 minutes with temperature $180^{\circ} \mathrm{C}$, removed from oven then cooled for 10 minutes and after cold, put into airtight container and ready to be analyzed.

\section{Observation:-}

The Observation this study consisted of two stages, namely observation on raw materials of banana flour include of water content and crude fiber while katuk leaves flour include of water content, crude fiber and Fe.

Then the observation of cookies that produced which include:

1. Chemical analysis: water content, ash content, protein content, fat content, carbohydrate content, crude fiber content (Sudarmadji, et al., 1997), Fe (SNI 19-2896-1992), free fatty acid (SNI 2973: 2011) and antioxidant activity (Huang, et al., 2005).

2. Physical analysis: hardness Analysis (Texture Analyzer Method)

\section{Results and Discussion:- \\ Raw Material Analysis:-}

The raw materials analyzed in this research were banana flour and katuk leaves flour. The results of raw material analysis can be seen in Table 2 .

The result of water content analysis of banana flour obtained was $7.74 \%$. While the results of water content of katuk leaves flour obtained was $8.15 \%$. When compared with the water content of wheat flour that is at least $14.5 \%$ (SNI 3751:2009), the water content of banana flour and katuk leaves flour that produced had meet the standard of SNI. The product in the form of flour is highly recommended to have low levels of water content so that it can be stored for longer periods of time because with low water content can inhibit the growth of microorganisms.

Analysis result of crude fiber content of banana flour obtained was 1.57\%, compared to Arifin research (2011), the crude fiber content of banana flour obtained was $1.96 \%$, and the content of crude fiber of banana flour obtained was slightly lower. While the crude fiber content of katuk leaves flour obtained was $2.46 \%$. The result of $\mathrm{Fe}$ in katuk leaves flour obtained was $0.06 \%$, compared to $\mathrm{Fe}$ in spinach flour which was $0.02 \%$, Fe content in katuk leaves flour was slightly higher than the spinach flour (Novita, 2005).

\section{Chemical Analysis of Cookies with Addition of Banana Flour and Katuk Leaves Flour:- Water Content:-}

The results of analysis of water content of cookies with the addition of banana flour and katuk leaves flour produced was ranged from $2.82 \%-4.24 \%$. The results of the analysis can be seen in Table 3 .

The result of variance showed that the addition of banana flour and katuk leaves flour had statistically significant effect $(\alpha<5 \% ; \mathrm{p}=0.034)$ on water content of cookies that produced. Table 3 shows the highest water content in $\mathrm{C}$ treatment (30\% banana flour and 15\% katuk leaves flour) with water content of $4.24 \%$ and the lowest water content found in cookies A ( $40 \%$ banana flour and $5 \%$ katukleaves flour ) With a water content of $2.82 \%$. The water content obtained meets the Quality Requirements of Cookies in accordance with SNI 2973: 2011 which is a maximum of 5.

Increased moisture content is suspected because the water content of katuk leaves flour is higher than the banana flour. Water content of katuk leaves flour $8.15 \%$ while banana water content $7.74 \%$, so the more katuk leaves addition causes the increase in water content. According to Winarno (2004), the water content in the foodstuffs contribute to the acceptance, freshness and endurance of the food. Water content can affect the appearance, texture, and taste of food. Most of the changes in foodstuffs occur in the water medium, whether added or derived from the material itself.

\section{Ash Content:-}

The result of ash content analysis of cookies with the addition of banana flour and katuk leaves flour ranged $1.17 \%$ $1.56 \%$. The results of the analysis can be seen in Table 4.

The result of variance showed that the addition of banana flour and katuk leaves flour had statistically significant effect $(\alpha<5 \% ; p=0.008)$ on ash content of cookies that produced. Table 4 shown the highest ash content found in cookies with treatment C (30\% banana flour and 15\% katuk leaves flour) with ash content of $1.56 \%$ and the lowest ash content found in treatment A (40\% banana flour and 5\% katuk leaves flour) with $1.17 \%$ ash content. 
From Table 4 also can be concluded that the higher the addition of katuk leaves flour, then the ash content of cookies produced increased. This was due to the ash content of katuk leaves was higher than the ash content of banana flour.

\section{Protein content:-}

The result of protein content analysis of cookies with the addition of banana flour and katuk leaves flour ranged $5.42 \%-6.87 \%$. The results of the analysis can be seen in Table 5 .

The result of variance showed that the addition of banana flour and katuk leaves flour had statistically significant effect $(\alpha<5 \% ; p=0.006)$ on protein content of cookies that produced. Table 5 shown the highest protein content found in cookies with treatment $\mathrm{C}(30 \%$ banana flour and 15\% katuk leaves flour) with a protein content of $6.87 \%$ and the lowest protein content found in treatment A (40\% banana flour and 5\% katuk leaves flour) of 5.42\%. Protein content obtained meets the Cookies Quality Requirement in accordance with SNI 2973: 2011 that is at least $5 \%$. Analysis result showed that the higher the addition of katuk leaves flour the higher the protein content of cookies. May the protein content of katuk leaves flour was higher than the banana flour.

Protein content depends on the amount of ingredients added. Based on research by Novita (2005) which analyzed protein content contained in katuk leaves flour of 29.15\%, while banana flour based on research by Pulungan (2015) obtained protein of $6.56 \%$. Increased protein content in cookies also affected by milk and eggs.

\section{Fat Content:-}

The result of fat content analysis of cookies with the addition of banana flour and katuk leaves flour ranged $17.98 \%$ - 19,42\%. The results of the analysis can be seen in Table 6.

The result of variance showed that the addition of banana flour and katuk leaves flour had statistically significant effect $(\alpha<5 \% ; p=0.001)$ on fat content of cookies that produced. Table 6 shown the highest fat content found in cookies with treatment $\mathrm{C}(30 \%$ banana flour and $15 \%$ katuk leaves flour) with a fat content of $19.43 \%$ and the lowest fat content found in cookies with treatment A (40\% banana flour and 5\% katuk leaves flour) of $17.32 \%$. Analysis results showed the higher the addition of katuk leaves flour, the higher fatty acid content. This was because the fat contained in katuk leaves flour was slightly higher than the fat content in banana flour. This increasement was also influenced by raw materials such as margarine, eggs and other raw materials.

According to Manley (2000), in the making of cookies, fat serves to improve the physical structure such as the shaper of taste, development and texture. Fats and oils are a more effective source of energy than carbohydrates and proteins (Winarno, 2004). Fat was the biggest component beside flour and sugar. The main function of fat in the making of cookies was as an emulsifier, in addition fat also served as a flavor maker and gave texture to the cookies. The more fat added to the dough, the more fragile the cookies produced (Manley, 2000)

\section{Carbohydrate Content:-}

The result of carbohydrate content analysis of cookies with the addition of banana flour and katuk leaves flour ranged $69.70 \%-70.79 \%$. The results of the analysis can be seen in Table 7 .

The result of variance showed that the addition of banana flour and katuk leaves flour had statistically no significant effect $(\alpha>5 \%, p=0.122)$ on carbohydrate content of cookies that produced. Table 7 shown the highest carbohydrate content found in cookies with treatment $\mathrm{C}$ (30\% banana flour and $15 \%$ katuk leaves starch) with carbohydrate of $70.79 \%$ and the lowest carbohydrate content found in cookies with treatment A (40\% banana flour and $5 \%$ katuk leaves flour) of $69.70 \%$.

\section{Crude Fiber Content:-}

The result of crude fiber content analysis of cookies with the addition of banana flour and katuk leaves flour ranged $1.90 \%-2.04 \%$. The results of the analysis can be seen in Table 8.

The result of variance showed that the addition of banana flour and katuk leaves flour had statistically no significant effect $(\alpha>5 \%, p=0.860)$ on crude fiber content of cookies that produced. The highest crude fiber content found in treatment $\mathrm{C}(30 \%$ banana flour and $15 \%$ katuk leaves flour) of $2.04 \%$ and the lowest crude fiber content found in treatment A (40\% banana flour and 5\% katuk leaves flour) of $1.90 \%$. 


\section{Fe content:-}

The result of Fe content analysis of cookies with the addition of banana flour and katuk leaves flour ranged $0.04 \%$ $0.05 \%$. The results of the analysis can be seen in Table 9 .

The result of variance showed that the addition of banana flour and katuk leaves flour had statistically significant effect $(\alpha<5 \%, \mathrm{p}=0.001)$ on Fe content of cookies that produced. The highest Fe content found in treatment $\mathrm{C}(30 \%$ banana flour and $15 \%$ katuk leaves flour) of $0.045 \%$ and the lowest Fe content found in treatment $\mathrm{A}$ and $\mathrm{B}$ of $0.04 \%$. From table 9 it can be seen that Fe content found in treatment $\mathrm{C}$ was higher compared with treatment $\mathrm{A}$ and $\mathrm{B}$. This was because the addition of katuk leaves flour on treatment $\mathrm{C}$ was higher than the treatment $\mathrm{A}$ and $\mathrm{B}$.

Katuk leaves flour contained Fe of $0.06 \%$. Total Fe obtained tend to be higher compared with the research by Novita (2005) on spinach of $0.02 \%$. According to Moehji (1992), iron (Fe) is an essential microelement for the body, this substance is especially needed in hematopoiesis (blood formation) in the synthesis of haemoglobin (Hb).

\section{Antioxidant Activity:-}

The result of antioxidant activity analysis of cookies with the addition of banana flour and katuk leaves flour ranged $10.49 \%-15.66 \%$. The results of the analysis can be seen in Table 10.

The result of variance showed that the addition of banana flour and katuk leaves flour had statistically significant effect $(\alpha<5 \% ; p=0.007)$ on antioxidant activity of cookies that produced. Table 10 shown the highest antioxidant activity found in treatment $\mathrm{C}(30 \%$ banana flour and $15 \%$ katuk leaves flour) of $15.66 \%$ and the loweest antioxidant activity found in treatment A (40\% banana flour and 5\% katuk leaves flour) od 10.49\%. the higher the addition of katuk leaves flour, the higher the antioxidant activity. This was because the antioxidant activity of katuk leaves flour was higher than antioxidant activity in banana flour.

According to Limantara (2004), Katuk rich of chlorophyll so that katuk had a high potential as a green natural colorant. According to Santoso (2013) Katuk also rich of pro-vitamin A (beta carotene), vitamin B, C, K, flavonoids and polyphenols. According to Kanazawa (2000), antioxidant which found in banana are Vitamin A, B, C, E, betacarotene and phenolic compounds such as catechin, epicatechin, tannin, flavonoid and anthocyanin. Phenolic compound is a natural compound that contained in foods and has a protective effect on the damage of oxidation in human body.

\section{Free Fatty Acid Content:-}

Free fatty acid is an acid that is freed in hydrolysis process of fat. The presence of free fatty acids in a foodstuff is usually used as an early indicator of the damage of fat due to hydrolysis process. In the process of hydrolysis, fat will be converted into free fatty acids and glycerol. The hydrolysis reaction which can cause damage to fat occurs due to the presence of a certain amount of water (Ketaren, 1986).

The result of free fatty acid analysis of cookies with the addition of banana flour and katuk leaves flour ranged $0.24 \%-0.28 \%$. The results of the analysis can be seen in Table 11 .

The result of variance showed that the addition of banana flour and katuk leaves flour had statistically no significant effect $(\alpha>5 \% ; p=0.605)$ on Free Fatty Acid content of cookies that produced. Table 11 shown the highest free fatty acid content found in cookies with treatment A (40\% banana flour and 5\% katuk leaves flour) of $0.28 \%$ and the lowest free fatty acid found in cookies with treatment C (30\% banana flour and 15\% katuk leaves flour) of $0.24 \%$.

According to quality standard in SNI 01-2973-2011, that is about quality requirement of cookies attached that maximum free fatty acid is $1 \%$. From the product of cookies produced with the addition of banana flour and katuk leaves flour obtained results that meets SNI quality standards.

Table 1:-Formulation of Cookies Ingredients.

\begin{tabular}{|c|c|c|c|}
\hline \multirow{2}{*}{ Material } & \multicolumn{3}{|c|}{ Treatment } \\
\cline { 2 - 4 } & A & B & C \\
\hline Wheat Flour (g) & 55 & 55 & 55 \\
\hline Banana Flour (g) & 40 & 35 & 30 \\
\hline Katuk Leaves Flour (g) & 5 & 10 & 15 \\
\hline
\end{tabular}




\begin{tabular}{|c|c|c|c|}
\hline Margarine (g) & 30 & 30 & 30 \\
\hline Refined Sugar (g) & 35 & 35 & 35 \\
\hline Egg yolk (g) & 17.5 & 17.5 & 17.5 \\
\hline Vanilla (g) & 1 & 1 & 1 \\
\hline Salt $(\mathrm{g})$ & 0.7 & 0.7 & 0.7 \\
\hline Baking Powder(g) & 0.2 & 0.2 & 0.2 \\
\hline Skim Milk (g) & 2.5 & 2.5 & 2.5 \\
\hline
\end{tabular}

Manley, 2000 with modification.

Table 2:-Result Analysis of Banana Flour and Katuk Leaves Flour

\begin{tabular}{|c|c|c|}
\hline Variable & Banana Flour & Katuk Leaves Flour \\
\hline Water Content (\%) & 7.74 & 8.15 \\
\hline Crude Fiber (\%) & 1.57 & 2.46 \\
\hline $\mathrm{Fe}(\%)$ & - & 0.06 \\
\hline
\end{tabular}

Table 3:-Water Content of Cookies.

\begin{tabular}{|c|c|}
\hline Treatment & \multicolumn{2}{|c|}{ Water Content (\%)(Average \pm SD) } \\
\hline A (WF 55\%:BF 40\%: KF 5\%) & $2.82 \pm 0.44 \quad$ a \\
\hline B (WF 55\%: BF 35\%:KF 10\%) & $3.72 \pm 0.29 \quad$ ab \\
\hline C (WF 55\%: BF 30\%: KF 15\%) & $4.24 \pm 0.67 \quad$ b \\
\hline CV $=13.80$ & \\
\hline
\end{tabular}

Table 4:-Ash Content of Cookies.

\begin{tabular}{|c|c|}
\hline Treatment & Ash Content (\%)(Average \pm SD) \\
\hline A (WF 55\%: BF 40\%: KF 5\%) & $1.17 \pm 0.17 \mathrm{a}$ \\
\hline B (WF 55\%: BF 35\%:KF 10\%) & $1.47 \pm 0.41 \quad \mathrm{~b}$ \\
\hline C (WF 55\%:BF 30\%: KF 15\%) & $1.56 \pm 0.39 \mathrm{~b}$ \\
\hline CV $=7.48$ & \\
\hline
\end{tabular}

Table 5:-Protein Content of Cookies.

\begin{tabular}{|c|c|}
\hline Treatment & Protein Content (\%)(Average \pm SD) \\
\hline A (WF 55\%: BF 40\%: KF 5\%) & $5.42 \pm 0.25 \mathrm{a}$ \\
\hline B (WF 55\%: BF 35\%:KF 10\%) & $6.07 \pm 0.54 \mathrm{a}$ \\
\hline C (WF 55\%:BF 30\%: KF 15\%) & $6.87 \pm 0.07 \quad \mathrm{~b}$ \\
\hline CV $=5.67$ & \\
\hline
\end{tabular}

Table 6:-Fat Content of Cookies

\begin{tabular}{|c|c|}
\hline Treatment & Fat Content (\%)(Average \pm SD) \\
\hline A (WF 55\% : BF 40\%: KF 5\%) & $17.32 \pm 0.56 \mathrm{a}$ \\
\hline B (WF 55\%: BF 35\%:KF 10\%) & $18.76 \pm 0.09 \mathrm{~b}$ \\
\hline C (WF 55\%: BF 30\%: KF 15\%) & $19.43 \pm 0.15 \mathrm{~b}$ \\
\hline CV $=1.84$ & \\
\hline
\end{tabular}

Table 7:-Carbohydrate Content of Cookies.

\begin{tabular}{|c|c|}
\hline Treatment & CarbohydrateContent (\%)(Average \pm SD) \\
\hline A (WF 55\%: BF 405: KF 5\%) & $69.70 \pm 0.51$ \\
\hline B ( WF 55\%: BF 35\%:KF 10\%) & $69.98 \pm 0.44$ \\
\hline C (WF 55\%: BF 30\%: KF 15\%) & $70.79 \pm 0.70$ \\
\hline CV $=0.79$ & \\
\hline
\end{tabular}

Table 8:-Crude Fiber Content of Cookies.

\begin{tabular}{|c|c|}
\hline Treatment & Crude Fiber Content (\%)(Average \pm SD) \\
\hline A (WF 55\%: BF 40\%: KF 5\%) & $1.90 \pm 0.28$ \\
\hline B ( WF 55\%: BF 35\%:KF 10\%) & $1.96 \pm 0.40$ \\
\hline
\end{tabular}




\begin{tabular}{|c|c|}
\hline C ( WF 55\% :BF 30\% : KF 15\%) & $2.04 . \pm 0.22$ \\
\hline CV $=15.75$ & \\
\hline
\end{tabular}

Table 9:-Fe Content of Cookies.

\begin{tabular}{|c|c|}
\hline Treatment & FeContent (\%)(Average \pm SD) \\
\hline A (WF 55\%: BF 40\%: KF 5\%) & $0.04 \pm 0.001 \mathrm{a}$ \\
\hline B (WF 55\%: BF 35\%:KF 10\%) & $0.04 \pm 0.002 \mathrm{a}$ \\
\hline C (WF 55\%: BF 30\%: KF 15\%) & $0.05 \pm 0.001 \mathrm{~b}$ \\
\hline CV $=1.96$ & \\
\hline
\end{tabular}

Table 10:-Antioxidant Activity of Cookies.

\begin{tabular}{|c|c|}
\hline Treatment & AntioxidantActivity (\%)(Average \pm SD) \\
\hline A ( WF 55\% : BF 40\% : KF 5\%) & $10.49 \pm 1.01$ a \\
\hline B (WF 55\% : BF 35\%:KF 10\%) & $13.07 \pm 1.75 \quad$ b \\
\hline C (WF 55\% :BF 305: KF 15\%) & $15.66 \pm 0.76 \quad$ c \\
\hline CV $=9.57$ & \\
\hline
\end{tabular}

Table 11:- Free Fatty Acid content of Cookies.

\begin{tabular}{|c|c|}
\hline Treatment & Free Fatty Acid (\%)(Average \pm SD) \\
\hline C (WF 55\%: BF 30\%: KF 15\%) & $0.24 \pm 0.00$ \\
\hline B (WF 55\%:BF 35\%:KF 10\%) & $0.26 \pm 0.03$ \\
\hline A (WF 55\% :BF 40\%: KF 5\%) & $0.28 \pm 0.08$ \\
\hline CV $=21.15$ & \\
\hline
\end{tabular}

Table 12:-Hardness Value of Cookies.

\begin{tabular}{|c|c|}
\hline Treatment & Hardness $\left(\mathrm{N} / \mathrm{cm}^{2}\right)($ Average \pm SD $)$ \\
\hline A (WF 55\%: BF 40\% : KF 5\%) & $7.95 \pm 0.45 \mathrm{a}$ \\
\hline B (WF 55\%: BF 35\% :KF 10\%) & $7.57 \pm 0.19 \quad a b$ \\
\hline $\mathrm{C}(\mathrm{EF} 55 \%$ : BF $30 \%: \mathrm{KF} 15 \%)$ & $7.07 \pm 0.16$ \\
\hline $\mathrm{CV}=3.98$ & \\
\hline
\end{tabular}

The numbers on the same lane followed by unequal small letters are significantly different at the 5\% Duncan's New Multiple Range Test (DNMRT) level.

$\mathrm{WF}=$ Wheat Flour $\mathrm{BF}=$ Banana Flour, $\mathrm{KF}=$ Katuk Leaves Flour

\section{Physical Analysis of Cookies with the addition of Banana Flour and Katuk Leaves Flour:-} Hardness:-

The result hardness analysis of cookies with the addition of banana flour and katuk leaves flour ranged $7.07 \mathrm{~N} / \mathrm{cm}^{2}$ $7.95 \mathrm{~N} / \mathrm{cm}^{2}$. The results of the analysis can be seen in Table 12 .

The result of variance showed that the addition of banana flour and katuk leaves flour had statistically significant effect $(\alpha<5 \% ; \mathrm{p}=0.031)$ on the hardness of cookies that produced. Table 12 shown the highest hardness value found in cookie with treatment $\mathrm{A}$ with a value of $7.95 \mathrm{~N} / \mathrm{cm}^{2}$. Based on the organoleptic test on the texture of cookies the most prefered cookies had a value of 4.03 on hardness that was treatment B with value of hardness of $7.57 \mathrm{~N} / \mathrm{cm}^{2}$.

The increasing hardness value represents an increasingly harder and less crunchy texture compared to products with low hardness values. This is in accordance with the statement of Indriyani (2007), which stated that the hardness of cookies is also influenced by the fiber content,the presence of fibers will form a harder structure. From the results obtained, the lower the fiber content the increased the level of hardness. Crude fiber content in treatment A of 1.90\% and cookies hardness value of $7.95 \mathrm{~N} / \mathrm{cm}^{2}$ while the crude fiber content in treatment $\mathrm{C}$ of $2.04 \%$ and cookies hardness of $7.07 \mathrm{~N} / \mathrm{cm}^{2}$. 


\section{Conclusions And Suggestions:- \\ Conclusion:-}

Based on the research that has been done it can be concluded:The addition of banana flour and katuk leaves flour to the cookies has a significant effect on ash content, water content, fat content, Fe content, antioxidant activity, protein content, and hardness. But it does not has a significant effect on crude fiber content, free fatty acid content and carbohydrates content.

\section{Suggestion:-}

For further researchers it is recommended to analysis the bioavailability of Fe, antioxidant activity and nutrient contained of cookies that produced.

\section{References:-}

1. Arifin, S. 2011. Studi Pembuatan Roti dengan Substitusi Tepung Pisang Kepok (Musa paradisiaca). Teknologi Pertanian. Universitas Andalas. Padang.

2. [BSN] Badan Standarisasi Nasional. 2011. SNI 2973:2011. Syarat Mutu Cookies. Badan Standarisasi Nasional : Jakarta.

3. [BSN] Badan Standarisasi Nasional. 1992. SNI 19-2896:1992. Cara Uji Cemaran Logam. Badan Standarisasi Nasional : Jakarta.

4. [BSN] Badan Standarisasi Nasional. 2009. SNI 3751:2009. Tepung Terigu sebagai Bahan Makanan. Badan Standarisasi Nasional. Jakarta.

5. Huang, Yu-Ching, Yung-Ho and Shao, Yi-Yuan. 2005. Effect of Genotype and Treatment on the Antioxidant Activity of Sweet Potato in Taiwan. Food Chemistry 98 (2006) 529-538

6. Indriyani. A., 2007. Cookies Tepung Garut (Moranta arundinaceae, L) dengan Pengayaan Serat Pangan. Jurusan Teknologi Pangan dan Hasil Pertanian-Fateta, UGM. Jogyakarta

7. Kanazawa. K.and H. Sakakibara. 2000. High Content of Dopamine, a Strong Antioxidant, in Cavendish Banana. Journal of Agricultural and Food Chemistry. 48(3), 844-848

8. Ketaren, S. 1986. Pengantar Minyak Atsiri. Balai Pustaka. Jakarta.

9. Limantara,L. 2004. Daya Penyembuhan Klorofil. Kompas. Available online at :htBF://www.kompas.com/kompas.cetak/0404/06/humaniora/951295.htm (accessed on October 15 $\left.{ }^{\text {th }}, 2006\right)$.

10. Lingga, P. 1998. Resep-Resep Obat Tradisional. Cetakan IV. Penebar Swadaya. Jakarta.

11. Manley, D. J. R. 2000. Technology of Biscuits, Crackers and Cookies. Ellis Horwood Limited. Chiecester Publisher. . United Kingdom

12. Matz, S. A. 1978. Cookies and Crackers. Ellis Horwood Limited. Chiecester Publisher. United Kingdom.

13. Moehji, S. 1992. Ilmu Gizi. Bhratara. Jakarta.

14. Mulyati, S. 2005. Aneka Olahan Pisang. Trubus Agrisarana. Surabaya.

15. Novita, R. 2005. Evaluasi Kadar Fe dan Serat Kasar Mie Kering yang Ditambah Tepung Bayam (Amaranthus $s p$ ). [Skripsi]. Teknologi Pertanian. Universitas Andalas. Padang.

16. Pulungan, R. 2015. Pengaruh Penambahan Tepung Pisang (Musa paradisiaca) dan Tepung Kacang Hijau (Phaeolus radiatus L) Terhadap Tepung Gandum (Triticum aestivum) dalam Pembuatan Cookies. [Skripsi]. Teknologi Pertanian. Universitas Andalas. Padang.

17. Santoso.U.,2013. Katuk, Tumbuhan Multi Khasiat. Badan Penerbit Fakultas Pertanian (BPFP) Unib. Bengkulu

18. Sudarmadji, S. Haryono, and B. Suhardi. 1997. Analisa Bahan Pangan dan Pertanian. Liberty. Yogyakarta.

19. Winarno, F. G. 2004. Kimia Pangan dan Gizi. PT. Gramedia Pustaka Utama :Jakarta. 